V.V.Hnatushenko, orcid.org/0000-0003-3140-3788,

T.A. Zheldak, orcid.org/0000-0002-4728-5889,

L. S. Koriashkina, orcid.org/0000-0001-6423-092X
Dnipro University of Technology, Dnipro, Ukraine, e-mail: zheldak.t.a@nmu.one

\title{
MATHEMATICAL MODEL OF STEEL CONSUMPTION MINIMIZATION CONSIDERING THE TWO-STAGE BILLETS CUTTING
}

Purpose. To achieve a decrease in energy and resource costs in the multi-stage production of rolled products within a given plan through the development of appropriate mathware.

Methodology. The multi-stage problem mathware for producing rolling steel products is developed on the basis of system approach applying fundamental principles of the optimization and operation research theory. Realization of the developed mathematical model allows discovering such a strategy of using steel during the whole manufacturing process, which minimizes not only the steel waste at the moment of its casting in a mold, but also the offcuts in the process of cutting the obtained ingots into the billets.

Findings. A mathematical task model is built to minimize the amount of steel for producing a certain order of size of one cast volume only. The developed model specifies the possibility to pre-evaluate the billet optimal size, based on the necessary cutting along the final product length, appropriate for the certain billet form of section, and ingot weight limits.

Originality. A mathematical model is provided for the optimal metal distribution process when implementing the plan of manufacturing rolling products. The model, in contrast to the existing ones, shifts the emphasis on forming the optimal ingot weight, which has a pre-calculated optimal cutting plan.

Practical value. The use of the developed mathematical optimization model (minimizing the amount of steel for producing a certain order) as part of an automated decision support system for management of rolling production will reduce the number of cutting machine changeover and minimize resources use and stock balance.

Keywords: casting, ingot, steel recovery rate, dimensionality, optimization, two-stage model

Introduction. In the current conditions of the development of metallurgical industry, one of the key tasks of any enterprise is to find the internal reserves for reducing costs and use of energy- and resource-efficient technological modes [1]. An important component of the economic activity of an enterprise is development of such production programs, in which much attention would be paid to the possibility of using secondary resources, reducing the specific costs of raw materials and energy resources; maximum use of raw materials stocks; minimizing downtime. In this regard, the relevant direction of research in the field of applied mathematics is system analysis of technological processes, application of methods of computational mathematics and optimization for quantitative substantiation the choice of this or that program of an enterprise functioning.

The problem of resources and energy saving is especially acute in the rolling production of a wide range of products. The exclusiveness of this issue is caused by the fact that a significant part of the metal losses at an enterprise is at final operations of a technological cycle when significant energy resources have already been embedded in the manufactured metal. One of the main criteria characterizing the efficiency of a metallurgical production, in particular rolling, is the metal consumable coefficient (MCC), which is equal to the ratio of $M_{\text {brutto }}$ weight of the metal consumed to fulfill a certain order to $M_{\text {netto }}$ weight of all the products for this order. The closer to 1 this coefficient is, the more efficient the whole set of technological operations performed between steel casting and shipment of the finished products is.

Regardless of the type of melting unit, the technological process of manufacturing rolling products contains a set of operations, each of which significantly affects the implementation of the following one(s). Traditionally, each of the operations is adjusted to a certain technological criterion of optimality based on the already known results of the previous operations.

Often, the problem of minimizing metal consumption in rolling production is solved at the stages of cutting finished

(c) Hnatushenko V.V., Zheldak T.A., Koriashkina L. S., 2021 products and (partially) cutting out ingots for billets. It is considered to be relevant to build such a plan for ingot formation, which, during the next operations, would allow cutting out billets and the finished products made from them with a minimum of possible cut-offs, thereby minimizing the metal consumable coefficient.

The object of this research is a two-stage process of metal distribution when producing rolling products.

The subject for the study is a mathematical model of the task for optimal metal use at the stage of casting steel from a ladle when in converter production, and formation of billets in machines with continuous casting that takes into account the type of product(s) to be produced from this metal as well as possible cutting out options in two process stages of rolling.

The purpose of this work is to provide reduction in energy and resource costs during the multi-stage production of rolled products within the specified plan by developing the appropriate mathematical support.

The relevance of the work is explained by one of the most common trends in mining and processing industries, namely, the development of such production programs, wherein much attention is drawn to the possibility of processing the production waste and the use of secondary resources; reducing specific costs of raw materials and energy resources; maximum use of raw material stocks, minimizing downtime of production equipment.

Problem definition. Rolled products are shipped to a customer taking into account the measure, i.e. it is necessary to produce as many profiles, pipes or other rolling products as possible from each of pre-cut billets, while keeping to the criteria for the minimum of metal consumption rate.

The generalized sequences of technological operations when producing graded rolled products and seamless pipes are given in Figure.

In their previous studies, the authors showed that a key factor, determining the amount of losses when cutting rolling products, is a mass of ingots $q$ which are then cut into precutting billets as well as the amount of burning loss in heating furnaces and the presence of additional cut-offs caused by poor quality of ingot rolling. 


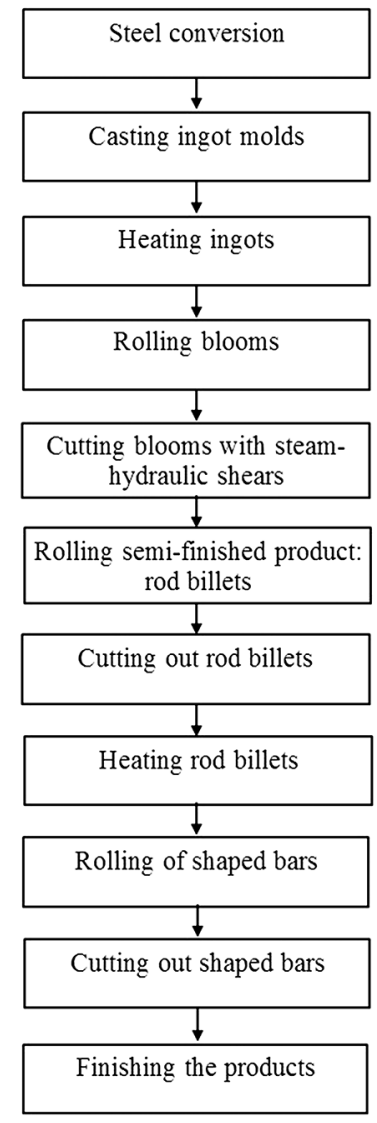

$a$

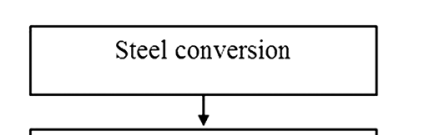

Casting ingot molds

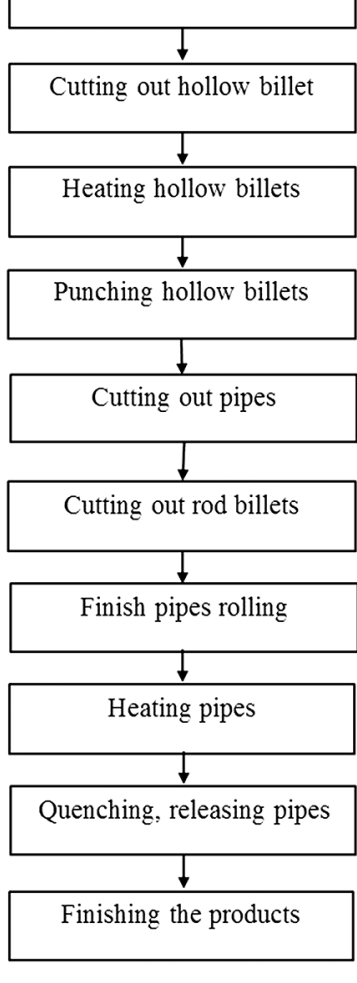

$b$

\section{Fig. Stages of technological production process:}

\section{$a$-graded rolled products; $b$ - seamless pipes}

The size of the processed billets for each type of finished product $L_{m}$ depends on the dimension of the rod $p$, into which the finished products will be cut out, and the furnace, in which the billets are heated before rolling. For example, if a shaped rolled steel or pipe is shipped by railroad transport in standard wagons, it is cut to 12 or 11.7 meter length. In the case of transportation by road, cutting to length of 9 or 6 meters can be used. Further, we take these four dimensions as possible values of the parameter $p=1,2,3,4$.

To make the whole amount of measured finished products $x_{m}$ from each billet, the billets must have a certain optimal length $L_{m}$, which takes into account the law of conservation of metal mass and will provide the minimum number of cut-offs when cutting an ingot with the number $n\left(l_{n}-\right.$ $\left.-\sum L_{m} X_{m}\right)$. For pre-cutting billets, there are usually upper and lower limits of length which are determined by the design of a heating furnace and a rolling unit. Accordingly, for an ingot into which the current portion of metal is divided in the furnace ladle, there are upper and lower weight limits $q_{\max } \leq q \leq q_{\text {min }}$.

Therefore, it is necessary to develop a mathematical model of dividing casting smelting $Q$ into ingots $q_{n}, n=1, \ldots, N$ aimed at minimizing the metal consumable coefficient by reducing the number of unmeasured products $F(q, x) \rightarrow$ min, taking into account cutting out of billets in two pre-cuttings.

Literature review. Most authors [2-13], who consider the task of optimal cutting of billets and workpieces in metallurgical production, take value of rollback length or weight of the ingot coming to the rolling plant from the steel casting site as the known or predictable value.

Some of the authors [2,3] suggest focusing on accuracy of the determining the length of a roll by using statistical methods [2] or optical sensors with an automated control system for the cutting mechanism [3].
Other researchers $[4,5]$ use a device of neural and neurofuzzy networks to predict the length of the bloom, which will be divided into pre-cut billets. At the same time, the construction of cutting cards is carried out, using the method of joint use of optimization methods and elements of simulation modeling.

The mathematical model of concurrent performing of orders for rolled steel products to be made from one steel grade, which is proposed in [5], is described in detail in [6], where a heuristic algorithm, which solves the problem in real time scale, is suggested. They also share the experimental studies on the algorithm based on the real data. Later the algorithm was proposed as a part of integrated control systems for multi-stage metallurgical production on the example of pipe rolling [7]. The authors of the latest works emphasize the need to derive a global target function (efficiency criterion) of multi-stage production.

The authors ambiguously consider the issue of formulating the target optimization function in rolling production. Thus, the works $[2,4,6,7]$ describe the minimum number of cutoffs (technological losses) per length unit of rolling products, while $[3,5]$ and [8] consider the amount of metal (in the number of ingots, pre-cut billets or by mass) used for manufacturing the current order as a target function which is minimized.

As shown in [8], this is possible only if the order for finished products considered as the current task does not exceed one cast by the metal weight. This approach is not really unacceptable, although it would seem to be too restrictive as the most powerful converters in Ukraine have a capacity of 300 tons and some orders are measured in thousands of tons. Firstly, most Ukrainian metallurgical enterprises (apart from foreign ones) are equipped with continuous casting machines. The latter allow us to consider discrete casting production as continuous (melting time even in a small converter is at least 20 minutes, in an electric furnace - up to 60 minutes). Therefore, provided that the chemical composition and other properties of steel in successive castings are ensured, it is possible to ensure such a sequence which will exceed any order in terms of the amount of the finished metal. Secondly, an order of arbitrary volume can mathematically be presented as a sequence of orders, the volume of which does not exceed the size of the casting. This allows performing large orders, distributing their parts into daily, shift tasks and tasks for each specific casting.

That is why further we consider the minimum of the metal used to fulfill the current order, which does not exceed the mass of the current casting as the target function.

Another situation connected with fulfilling so called "urgent' orders that make one to change the production plan (usually Week plan with daily and shift details) right during a shift is examined in the works $[8,9]$. The situations are considered when a certain "urgent" order should start immediately from the current casting concurrently with fulfilling the order planned for the shift or even be performed earlier than the planned one. A condition for the concurrent fulfilling several orders or transition from one order to the other is similarity of cross-cuts (a type) of the bloom, which in an ingot is rolled out, in addition to similarity of an ingot steel grade.

Table 1 lists the intersections of rectangular pre-cut billet used in the production of channels of various brands produced by PJSC "DMZ” (Dnipro). As we see, for example, channel $10 \mathrm{U}$ can be obtained from the same ingot as channels $12 \mathrm{U}$, $14 \mathrm{U}$ and $16 \mathrm{U}$ as the pre-cut billets for all these profiles has a cross section of $150 \times 150 \mathrm{~mm}$. When there is a wide range of rolling products of one type of pre-cut billets, up to ten types of finished products can be produced.

The paper [10] provides a broad overview of methods for solving one-dimensional cutting problems, covering both single-stage and two-stage production processes. It is emphasized that varying the lengths of cutting at the first stage can significantly reduce or even eliminate metal loss at the second stage if there are no violations of the technological process. 
Use of billets when producing shaped rolling products (channels) at Private Joint Stock Company "DMZ"

\begin{tabular}{|c|c|c|c|c|c|c|c|c|c|c|}
\hline \multirow{2}{*}{ Shape } & \multirow{2}{*}{ Specifications } & \multirow{2}{*}{$\begin{array}{c}\text { Height } \\
\text { of flange, } \\
\text { mm }\end{array}$} & \multirow{2}{*}{$\begin{array}{c}\text { Mass } \\
1 \mathrm{~m} / \mathrm{kg}\end{array}$} & \multirow{2}{*}{$\begin{array}{c}\text { Billet } \\
\text { cross-section, } \\
\mathrm{mm}\end{array}$} & \multirow{2}{*}{$\begin{array}{l}\text { Billet } \\
\text { length, } \\
\mathrm{m}\end{array}$} & \multirow{2}{*}{$\begin{array}{l}\text { Length of } \\
\text { bloom, } \\
\text { m }\end{array}$} & \multirow{2}{*}{$\begin{array}{c}\text { Rod } \\
\text { length, } \\
\mathrm{m}\end{array}$} & \multirow{2}{*}{$\begin{array}{l}\text { Number } \\
\text { of rods, } \\
\text { pcs }\end{array}$} & \multicolumn{2}{|c|}{ Cut-offs, } \\
\hline & & & & & & & & & $\mathrm{m}$ & $\%$ \\
\hline \multirow[t]{3}{*}{ Channel 8U } & \multirow[t]{3}{*}{ TU U-14-2-1185-97 } & 40 & 7.034 & $125 \times 125$ & 2.40 & 39.8 & 12.0 & 3 & 3.78 & 9.51 \\
\hline & & 40 & 7.034 & $125 \times 125$ & 2.90 & 48.1 & 12.0 & 4 & 0.07 & 0.15 \\
\hline & & 40 & 7.034 & $125 \times 125$ & 3.20 & 53.0 & 12.0 & 4 & 5.04 & 9.51 \\
\hline \multirow[t]{3}{*}{ Channel 10U } & \multirow[t]{3}{*}{ TU U-14-2-1185-97 } & 46 & 8.580 & $150 \times 150$ & 2.40 & 47.0 & 12.0 & 3 & 10.96 & 23.35 \\
\hline & & 46 & 8.580 & $150 \times 150$ & 3.10 & 60.7 & 12.0 & 5 & 0.66 & 1.09 \\
\hline & & 46 & 8.580 & $150 \times 150$ & 3.20 & 62.6 & 12.0 & 5 & 2.62 & 4.18 \\
\hline \multirow[t]{3}{*}{ Channel 12U } & \multirow[t]{3}{*}{ TU U-14-2-1185-97 } & 52 & 10.216 & $150 \times 150$ & 2.40 & 39.4 & 12.0 & 3 & 3.44 & 8.73 \\
\hline & & 52 & 10.216 & $150 \times 150$ & 2.95 & 48.5 & 12.0 & 4 & 0.48 & 1.00 \\
\hline & & 52 & 10.216 & $150 \times 150$ & 3.20 & 52.6 & 12.0 & 4 & 4.59 & 8.73 \\
\hline \multirow[t]{3}{*}{ Channel 14U } & \multirow[t]{3}{*}{ TU U-14-2-1185-97 } & 58 & 12.066 & $150 \times 150$ & 2.40 & 33.4 & 12.0 & 2 & 9.40 & 28.14 \\
\hline & & 58 & 12.066 & $150 \times 150$ & 2.60 & 36.2 & 12.0 & 3 & 0.18 & 0.50 \\
\hline & & 58 & 12.066 & $150 \times 150$ & 3.20 & 44.5 & 12.0 & 3 & 8.53 & 19.15 \\
\hline \multirow[t]{3}{*}{ Channel 16U } & \multirow[t]{3}{*}{ TU U-14-2-1185-97 } & 64 & 13.825 & $150 \times 150$ & 2.40 & 29.1 & 12.0 & 2 & 5.14 & 17.63 \\
\hline & & 64 & 13.825 & $150 \times 150$ & 3.00 & 36.4 & 12.0 & 3 & 0.42 & 1.16 \\
\hline & & 64 & 13.825 & $150 \times 150$ & 3.20 & 38.9 & 12.0 & 3 & 2.86 & 7.37 \\
\hline \multirow[t]{3}{*}{ Channel 18U } & \multirow[t]{3}{*}{ TU U-14-2-1185-97 } & 70 & 16.164 & $170 \times 170$ & 2.40 & 32.0 & 12.0 & 2 & 8.02 & 25.05 \\
\hline & & 70 & 16.164 & $170 \times 170$ & 2.75 & 36.7 & 12.0 & 3 & 0.69 & 1.88 \\
\hline & & 70 & 16.164 & $170 \times 170$ & 3.20 & 42.7 & 12.0 & 3 & 6.69 & 15.68 \\
\hline \multirow[t]{3}{*}{ Channel 20U } & \multirow[t]{3}{*}{ TU U-14-2-1185-97 } & 78 & 18.414 & $170 \times 170$ & 2.40 & 28.0 & 12.0 & 2 & 3.98 & 14.22 \\
\hline & & 78 & 18.414 & $170 \times 170$ & 3.15 & 36.7 & 12.0 & 3 & 0.72 & 1.96 \\
\hline & & 78 & 18.414 & $170 \times 170$ & 3.20 & 37.3 & 12.0 & 3 & 1.30 & 3.49 \\
\hline \multirow[t]{3}{*}{ Channel 22U } & \multirow[t]{3}{*}{ TU U-14-2-1185-97 } & 82 & 20.527 & $135 \times 280$ & 2.40 & 33.0 & 12.0 & 2 & 9.02 & 27.32 \\
\hline & & 82 & 20.527 & $135 \times 280$ & 2.65 & 36.5 & 12.0 & 3 & 0.46 & 1.27 \\
\hline & & 82 & 20.527 & $135 \times 280$ & 3.20 & 44.0 & 12.0 & 3 & 8.03 & 18.24 \\
\hline \multirow[t]{3}{*}{ Channel 24U } & \multirow[t]{3}{*}{ TU U-14-2-1185-97 } & 90 & 23.698 & $135 \times 280$ & 2.40 & 28.4 & 12.0 & 2 & 4.44 & 15.62 \\
\hline & & 90 & 23.698 & $135 \times 280$ & 3.05 & 36.3 & 12.0 & 3 & 0.30 & 0.84 \\
\hline & & 90 & 23.698 & $135 \times 280$ & 3.20 & 38.1 & 12.0 & 3 & 2.09 & 5.48 \\
\hline Channel 30U & TU U-14-2-1185-97 & 100 & 32.090 & $135 \times 280$ & 2.40 & 21.1 & 12.0 & 1 & 9.10 & 43.12 \\
\hline & & 100 & 32.090 & $135 \times 280$ & 2.75 & 24.2 & 12.0 & 2 & 0.17 & 0.71 \\
\hline & & 100 & 32.090 & $135 \times 280$ & 3.20 & 28.1 & 12.0 & 2 & 4.13 & 14.68 \\
\hline
\end{tabular}

This approach is developed in [11], where a combined binary-integer mathematical model is proposed for cutting a bloom in the pre-cut billets and finished products on the rods provided that rod length is standard (measured). The main requirement to applying this model is optical control of the nondivided bloom cut-offs for prompt decision-making on changing the length of the pre-cut billets. The model implies the transition from one order to another (with a change in the type of products) when rolling metal from one casting. Use of the described approaches is technologically impossible at most domestic metallurgical plants. However, it seems rational to use the proposed approach, according to which having one or more optimal templates for cutting finished products at the last stage; the optimal cutting of a pre-cut billet is calculated.

It should also be noted that in [11], as in the majority of other sources, the weight of an ingot, and as a result, the length to which it is rolled out in the form of a bloom is an uncontrollable value. That is, ingots are fed in as they were casted without anticipating this or that option of cutting in advance.

The heuristic approach with the generation sequences of billets and their exchanges, according to the Gomory scheme given in [12], considers the problem of cutting as a one-dimensional optimization task in the real space, followed by rounding the results. Despite the high productivity and accuracy declared by the authors compared to the method of branches and boundaries, the proposed algorithm does not imply manufacturing several types of products from one type of billets.

In [13] the problem of minimizing the number of ingots to fulfill a known in advance order is solved as well. Moreover, the authors emphasize that reconfiguration of a cutting mechanism to a new length of pre-cut billets leads to time consumption that can economically be compared with losses from possible cutting waste. Accordingly, as one of the elements of the target function, a component responsible for the minimum reconfigurations of a cutting mechanism (minimum of different lengths of pre-cut billets cut out from one bloom) is proposed.

This study takes into account some constructive approaches to solving the known problem as well as offers the mathematical model which will allow considering specificity of a production process and overcoming the limitations of the approaches examined above. 
Methods and results. To build a mathematical model for minimizing metal consumption in two-stage production, we will first clarify some details of the production technology as well as make several assumptions regarding the initial data that is rooted in the technological process at the basic enterprise of PJSC "DMZ".

So, liquid metal is produced in portions of $Q$ tons (at the basic enterprise $Q=60 \pm 2 t$ ). After its casting, the mass of metal in the ladle is measured by crane scales with an error of no more than $30 \mathrm{~kg}$.

The molten metal is poured into the casting ingot molds (their standard number is $N=8-$ as many as can be placed on one railway platform), each of which $n=1, \ldots, N$ can take a mass of metal $q_{n}$ within the range from $q_{\min }=4.400$ to $q_{\max }=7.400 \mathrm{~kg}$ of the liquid metal. At the same time, there is a need to have metal in the ladle in the amount of about $400 \mathrm{~kg}$ (sedimentary substances) which will be used in the next casting. This production stage gives rise to the first restrictions of our model

$$
\begin{gathered}
q_{1}+q_{1}+\ldots+q_{N} \leq Q ; \\
q_{\min } \leq q_{n} \leq q_{\max }, \quad n=\overline{1, N} .
\end{gathered}
$$

Further, according to the scheme given in Fig. 1,a), the metal is poured into the blooms of certain sections, rolled out and cut. To indicate the bloom variant to be used to fulfill the current order, we introduce index $i$, which takes the value $i=1$, $2, \ldots, I$, where $I$ is the total number of bloom variants used in the production. The cross section of the bloom $a_{i} \times c_{i}$ is established according to the type of the products produced. The relationship between the bloom number and its intersection is illustrated in Table 2.

For each type of product $m$ from the range of $M(m=1,2, \ldots$, $M$ ) there is a certain line in Table 1 , which determines the binding of this type of product to a certain variant of the bloom. As can be seen from Table 1, some variants of bloom imply production of not only one type of a finished product, but several ones at once (up to 5). This allows maximizing the entire length of the produced bloom (the whole mass of the casted ingot) by combining the length of the pre-cut billets in different quantities,

Cutting of an ingot for producing a given amount of finished products (in accordance with the order) is carried out in two stages. At the first stage, the entire ingot is divided into pre-cut billets, the length of which can be within the range from 2.4 to $3.2 \mathrm{~m}$ with the increment of $0.05 \mathrm{~m}$. At the second stage, each pre-cut billet is rolled out into the finished product (a channel, angle, beam, pipe and so on) and cut into measuring rods of the given length in accordance with the order (determined by the logistical requirements of the customer). The number of the cutting type is further denoted by $p$. The latter takes the value $p=\{1,2,3,4\}$ that means cutting by $12,11.7,9$ or $6 \mathrm{~m}$ respectively.

When building a model, we assume that:

1) it is possible to estimate in advance the number of blooms of a certain $w_{i}$ section which should be used to make products according to plan $b_{m}$ with cutting $p$;

Table 2

Variants and cross sections of blooms

\begin{tabular}{|c|c|}
\hline Number of a variant & Cross section \\
\hline 1 & $125 \times 125$ \\
\hline 2 & $135 \times 280$ \\
\hline 3 & $150 \times 150$ \\
\hline$\ldots$ & $\ldots$ \\
\hline$i$ & $a_{i} \times c_{i}$ \\
\hline$\ldots$ & $\ldots$ \\
\hline$I$ & $230 \times 100$ \\
\hline
\end{tabular}

2) an one-to-one correspondence between the ingot molds and blooms is determined, i.e., it is known from which mold ingot billet metal is rolled into the bloom of a given cross section;

3) each pre-cut billet is cut into rods of one size only (a part of the finished products is of $12 \mathrm{~m}$ long, and a part, for example, of $9 \mathrm{~m}$ is not allowed);

4) for each type of the finished product and accordingly each variant of the bloom, the optimal length $L_{m}$ of the pre-cut billet is calculated in advance, which depends on the final cutting $p$. For each channel, there is a line highlighted in bold (Table 1) which corresponds to the optimal length of the precut billet within the specified limits of $2.4 m \leq L_{m} \leq 3.2 m$.

As a rule, this length of the pre-cut billet is one, though for some types of the finished products there can be some lengths in accordance with multiplicity of the rods of the finished product to which this billet will be cut in the future (maximum three). In this case, the final cutting $p$ is a key to cutting the pre-cut billets. Table 3 demonstrates optimal lengths of the pre-cut billets, which ensures the minimum cut-offs of rolling after obtaining the maximum number of rods of a certain length: for channel $8 \mathrm{U}$ in accordance with standard - specification TU U-14-2-1185-97 (flange height is $40 \mathrm{~mm}$, weight of $1 \mathrm{~m}$ of the finished product is $7.034 \mathrm{~kg}$, made from the billet with cross section of $125 \times 125 \mathrm{~mm}$ ).

We offer a mathematical model for the task on optimizing the production plan, taking into account all the technological processes. Here, in contrast to the known approaches, we formulate the problem of distribution of the existing metal between the ingot molds in such a way that cutting of the ingots obtained from them into pre-cut billets provides a minimum number of cut-offs at this and the next stages of rolling shaped profiles. In other words, it is necessary to minimize the amount of metal from which the products are manufactured in accordance with an order, providing minimum cuttings in the following operations.

To build the mathematical model for the task of the optimal production, we further assume that an order comes to a rolling plant in the form of a production plan $b$ in the table, where the row $m=1,2, \ldots, M$ corresponds to the type of product, and the column $p=1,2,3,4$ is a variant of cut. For each combination of $m$ and $p$ the following values are known in advance:

- $L_{m}^{p}$ - the optimal length of a pre-cut billet for producing the correspondent product (Table 1);

- $A_{m}^{p}$ - the number of rods of the correspondent products obtained after cutting one billet of $L_{m}^{p}$ length;

- $R_{m}^{p}$ - minimum waste of an ingot after its cutting for producing the correspondent products.

Table 4 contains connections between the types of products, variants for cutting them and the parameters of the precut billet at the stage of cutting out finished products, which are known in advance. In fact, Table 4 is an expanded Table 1

Table 3

Optimal length of a pre-cut billet of channel $8 \mathrm{U}$ depending on the rod length

\begin{tabular}{|l|c|c|c|c|}
\hline \multicolumn{1}{|c|}{ Technological parameter } & \multicolumn{4}{c|}{ Variants of rolling } \\
\hline Length of the finished product, $\mathrm{m}$ & 11.7 & 12 & 9 & 6 \\
\hline $\begin{array}{l}\text { Mass of 1 running meter, in } \\
\text { accordance with specification TU, } \mathrm{kg}\end{array}$ & 7.034 & 7.034 & 7.034 & 7.034 \\
\hline Optimal billet length, $\mathrm{m}$ & 2.85 & 2.9 & 2.75 & 2.9 \\
\hline Cogged ingot length, $\mathrm{m}$ & 47.2 & 48.1 & 45.6 & 48.1 \\
\hline Number of rods, pcs & 4 & 4 & 5 & 8 \\
\hline Cut-offs, $\mathrm{m}$ & 0.44 & 0.07 & 0.58 & 0.07 \\
\hline Cut-offs, $\%$ & 0.94 & 0.15 & 1.28 & 0.15 \\
\hline
\end{tabular}


Table 4

Linking an order to the optimal parameters of pre-cut billets

\begin{tabular}{|c|c|c|c|c|c|c|}
\hline $\begin{array}{c}\text { Indices, } \\
m, p\end{array}$ & Shape & $\begin{array}{c}\text { Rod } \\
\text { length, } \\
\mathrm{m}\end{array}$ & 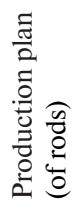 & 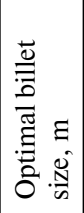 & 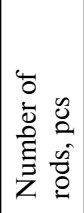 & 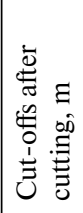 \\
\hline 1.1 & Channel $8 \mathrm{U}$ & 12 & $b_{1}^{1}$ & 2.9 & 4 & 0.07 \\
\hline 1.2 & & 11.7 & $b_{1}^{2}$ & 2.85 & 4 & 0.44 \\
\hline 1.3 & & 9 & $b_{1}^{3}$ & 2.75 & 5 & 0.58 \\
\hline 1.4 & & 6 & $b_{1}^{4}$ & $\ldots$ & & \\
\hline 2.1 & Channel 10U & 12 & $b_{2}^{1}$ & & & \\
\hline 2.2 & & 11.7 & $b_{2}^{2}$ & & & \\
\hline 2.3 & & 9 & $b_{2}^{3}$ & & & \\
\hline 2.4 & & 6 & $b_{2}^{4}$ & & & \\
\hline$\ldots$ & $\ldots$ & $\ldots$ & $\ldots$ & $\ldots$ & $\ldots$ & $\ldots$ \\
\hline$m \cdot p$ & Product m & $l_{p}$ & $b_{m}^{p}$ & $L_{m}^{p}$ & $A_{m}^{p}$ & $R_{m}^{p}$ \\
\hline$\cdots$ & & & $\cdots$ & $\cdots$ & $\cdots$ & $\cdots$ \\
\hline$M, 4$ & Product $M$ & & $b_{M}^{p}$ & & & \\
\hline
\end{tabular}

for all the variants of cutting all the names of finished pro ducts.

The number of billets with the optimal length in accordance with Table 4 that is necessary to obtain from the bloom for fulfilling the current order is calculated in the following way

$$
Z_{m}^{p}=b_{m}^{p} / A_{m}^{p}, \quad m=\overline{1, M} .
$$

As it is emphasized above, each product should be produced from a certain type of bloom with a certain cross section. In order to establish an one-to-one relationship between types of bloom and the range of manufactured products, it is proposed to use binary matrix $H$, which consists of $I$ rows (by the number of possible variants of bloom) and $M$ columns (by the number of possible types of products). Each element $h_{i m}$ is equal to " 1 " if $i$-type products can be obtained from the $i^{\text {th }}$ bloom, and otherwise - " 0 ".

The general view of matrix $H$ is illustrated by Table 5 . It is easy to notice that each column of this matrix contains only one 1. At the same time, since several types of finished products can be made from blooms of the same section, each line can have several elements of 1 (up to a dozen).

As it was mentioned above, the paper considers a simplified model of the problem, wherein it is assumed that one metal casting is enough to fulfill the current order.

Table 5

Relationship between blooms and products

\begin{tabular}{|c|c|c|c|c|c|c|c|c|}
\hline \multirow{2}{*}{ Bloom variant } & \multicolumn{7}{|c|}{ Type of product } \\
\cline { 2 - 10 } & 1 & 2 & 3 & $\ldots$ & $m$ & $\ldots$ & $M-1$ & $M$ \\
\hline 1 & 1 & 0 & 0 & $\ldots$ & 0 & $\ldots$ & & 0 \\
\hline 2 & 0 & 0 & 0 & $\ldots$ & 0 & $\ldots$ & 1 & 1 \\
\hline 3 & & & 1 & $\ldots$ & & & 0 & 0 \\
\hline$\ldots$ & & & & $\ldots$ & & $\ldots$ & & \\
\hline$I$ & & & & $\ldots$ & $h_{i m}$ & $\ldots$ & & \\
\hline$\ldots$ & & & & $\ldots$ & & $\ldots$ & & \\
\hline$I$ & & & & $\ldots$ & & $\ldots$ & & \\
\hline
\end{tabular}

Then, to solve the problem, the following condition must be fulfilled

$$
\sum_{p=1}^{4} \sum_{m=1}^{M} g_{m}^{p} b_{m}^{b} \leq Q
$$

where $g_{m}^{p}$ is weight of 1 rod of the correspondent products, calculated as a mass of 1 run meter of the product per rod length $l_{p}$.

Taking into consideration all the above as well as the limit (2), we now will evaluate how many blooms and of what cross section should be used to fulfill the order

$$
\frac{\sum_{p=1}^{4} \sum_{m=1}^{M} g_{m}^{p}\left(b_{m}^{b} \cdot h_{i m}\right)}{q_{\max }} \leq w_{i} \leq \frac{\sum_{p=1}^{4} \sum_{m=1}^{M} g_{m}^{p}\left(b_{m}^{b} \cdot h_{i m}\right)}{q_{\min }}, i=\overline{1, I} .
$$

Here, $q_{\max }$ and $q_{\min }$ are the maximum and minimum weight of the bloom in accordance with technological restrictions. Since the number of casting ingot billets is related to the number of blooms used, the number of blooms that will be poured from the current ladle and will go to fulfill the current order should be equal to

$$
\sum_{i=1}^{I} w_{i}=N
$$

Taking into account $(5,6)$ and the fact that during rolling each casting ingot becomes a certain type of bloom, we will introduce the binary matrix $D$, dimensions $I \times N$, which will unequivocally connect the bloom cross section with the ingot number. Each element $d_{i m}$ is equal to " 1 " if a bloom of the $i$-type is made from the $n^{\text {th }}$ casting ingot billet, and otherwise - to " 0 ".

The length of the bloom from the $n^{\text {th }}$ casting ingot mold after rolling is calculated by the formula

$$
l_{n}=\frac{q_{n}}{\bar{a}_{n} \bar{c}_{n} \rho}, \quad n=\overline{1, N}
$$

where $r$ is metal density $\left(\mathrm{kg} / \mathrm{m}^{3}\right)$, it depends on the steel grade, for the most common steel $5 \mathrm{ps} r=7856 \mathrm{~kg} / \mathrm{m}^{3} ; \bar{a}_{n}, \bar{c}_{n}$ is the dimensions of the bloom cross section, formally they can be calculated as follows

$$
\bar{a}_{n}=\sum_{i=1}^{I} d_{i n} a_{i} ; \quad \bar{c}_{n}=\sum_{i=1}^{I} d_{i n} c_{i} ; \quad n=\overline{1, N} .
$$

Let us define the number of billets with length $L_{m}^{p}$, which we get after cutting out the $n^{\text {th }}$ bloom, by $x_{m}^{p n}$. The number (quantity) of these variables is much smaller than the number of possible combinations $4 \times N \times M$. It is determined as follows: if the value

$$
\sigma_{m n}=\sum_{i=1}^{I} h_{i m} d_{i n}
$$

equals 1 , it corresponds to four variables that can only accept whole non-negative values. When $\sigma_{m n}=1$, the variable $x_{m}^{p n}$ does not exist.

Taking into account the statements (3-9) and the auxiliary variables introduced by us above, the mathematical model of the problem of minimizing the amount of metal used to fulfill the current order, which does not exceed the current casting (1), can be written in such a way: you need to find the values of $q_{n}$ and $x_{m}^{p n}$ with possible coefficients $n=1,2, \ldots, N ; m=1$, $2, \ldots, M$ and $p=1,2,3,4$ at which the function

$$
F(q, x)=\sum_{n=1}^{N}\left(l_{n}-\left.\sum_{m=1}^{M} \sum_{p=1}^{4}\left(L_{m}^{p} \cdot x_{m}^{p, n}\right)\right|_{\sigma_{m n}=1}\right),
$$

is minimal and meets the restrictions (1) as well as the conditions below 


$$
\begin{gathered}
\sum_{n=1}^{N} x_{m}^{p, n} \geq Z_{m}^{p}, \quad m=\overline{1, M}, p=\overline{1,4} \\
\left.\sum_{m=1}^{M} \sum_{p=1}^{4}\left(L_{m}^{p} \cdot x_{m}^{p, n}\right)\right|_{\sigma_{m n}=1}-\frac{q_{n}}{\bar{a}_{n} \bar{c}_{n} \rho} \leq 0, \quad n=\overline{1, N} \\
x_{m}^{p, n} \geq 0, x_{m}^{p, n} \text {-integers, } \quad m=\overline{1, M} ; n=\overline{1, N}: \sigma_{n m}=1 .
\end{gathered}
$$

The formulated task suggests saving material resources by minimizing the metal spent on the production and the time of execution orders by reducing the number of adjustments to the cutting mechanism in the production of the planned number of products.

Considering certain technological assumptions and conditions, a similar model can be built for any other rolling production, which involves two pre-cut ingots. The described approach can be used to optimize the production of pipes, wheels, profiled rolled products and other rolling products.

The constructed mathematical model is the task of partially integer linear programming. To solve it, you can use either Gomory cutting plane methods or, combinatorial methods, for example, the method of branches and borders, or heuristic algorithms.

Conclusions. The task of constructing a mathematical model of minimization the amount of metal used for fulfilling a certain order, the size of which does not exceed the volume of one casting, is set and solved in this work. The developed model takes into account the possibility to evaluate in advance the optimal size of the pre-cut billet on the basis of the desired cutting out along the length of the finished products permissible for these product types (intersections) of pre-cut billet and restrictions in the weight of one ingot at its top and bottom.

The scientific novelty of the approach to building this model is that, unlike most sources, the emphasis of optimization is transferred from the combination of the length of cutting out the finished ingot resulted from casting to the formation of the optimal weight of this ingot, which has the optimal cutting out, calculated in advance.

The use of the developed mathematical model of minimization the amount of metal used for fulfilling a certain order as part of an automated decision-making support system for rolling production management will reduce the number of changeovers of cutting machines and minimize the use of resources and product wastes in stock. These factors determine practical relevance of the work.

The prospect of the research development in the direction chosen by the authors is, first of all, the extension of the mod$\mathrm{el}$ in case if the order size exceeds the size of casting as well as in case of concurrent fulfillment of several orders for rolling products from the same steel grade. It is obvious that such model extension will provide another target function, and, conceivably, other methods for solving the problem.

The actual direction of further research also involves experimental verification of the proposed mathematical approach in real production conditions and assessment of accuracy and stability of the solutions that the developed model gives when executing real orders.

\section{References.}

1. Mazur, V.L. (2019). Theory and rolling technology: unsolved problems and development aspects. Metal and Casting of Ukraine, 5-6(312-313), 48-55. https://doi.org/10.15407/ steelcast2019.05.048.

2. Son, D., Kim, B.-I., Bae, B., Park, J.-S., \& Ki, Y. (2016). An algorithm for a cutting problem in window frame production. International Journal of Production Research, 54(14), 4327-4339. https://doi.org/10.1080/00207543.2016.1148279. 3. Muter, İ., \& Sezer, Z. (2018). Algorithms for the one-dimensional two-stage cutting stock problem. European Journal of Operational Research, 271(1), 20-32. https://doi. org/10.1016/i.ejor.2018.04.042.
4. Pitombeira-Neto, A.R., \& Prata, B.d.A. (2020). A matheuristic algorithm for the one-dimensional cutting stock and scheduling problem with heterogeneous orders. TOP 28, 178-192. https://doi.org/10.1007/s11750-019-00531-3. 5. Garraffa, M., Salassa, F., Vancroonenburg, W., Vanden Berghe, G., \& Wauters, T. (2016). The one-dimensional cutting stock problem with sequence-dependent cut losses. International Transactions in Operational Research, 23(1-2), 5-24. https://doi.org/10.1111/itor.12095.

6. Powar, P., \& Samuel, Siby (2018). One Dimensional Cutting Stock Problem (1D-CSP): A New approach for Sustainable Trim Loss. International journal of computer sciences and engineering, 6, 265-271. https://doi.org/10.26438/ijcse/v6i10.265271. 7. Sezer, Z., \& Muter, İ. (2016). Two-Stage Cutting Stock Problem with Due Dates. In A. Fink, A. Fügenschuh, \& M. Geiger (Eds.). Operations Research Proceedings, (pp. 139145). Springer, Cham. https://doi.org/10.1007/978-3-31955702-1_20.

8. Khan, R., Pruncu, C. I., Khan, A. S., Naeem, K., Abas, M., Khalid, Q.S., \& Aziz, A. (2020). A Mathematical Model for Reduction of Trim Loss in Cutting Reels at a Make-to-Order Paper Mill. Applied Sciences, 10(15), 5274.

9. Powar, P. L., \& Samuel, S. (2017). Comparative study of various algorithms dealing with computational aspects of onedimensional cutting stock problem. Advances in Computational Sciences and Technology, 10(3), 409-422. Retrieved from http://www.ripublication.com/acst17/acstv10n3 07.pdf .

10. Santos, J. L., Santos, J., Ferreira, M. J., Alves, N., \& Guevara, M. (2018). Application of the Two-Stage One-Dimensional Cutting Stock Problem in the Steel Industry. IEEE 27 $7^{\text {th }}$ International Symposium on Industrial Electronics (ISIE), Cairns, QLD, (pp. 683-690). https://doi.org/10.1109/ ISIE.2018.8433734.

11. Karmalita, O. Yu., \& Kravchenko, V.P. (2020). Automation of the cutting process for uninterrupted pouring into specific cut length with minimum cuttings. Perspektyvy rozvytku suchasnoi nauky i tekhniky: zbirnyk tez dopovidei Vseukrainskoi internet-konferentsii, Mariupol, (pp. 26-27).

12. Wang, D., Xiao, F., Zhou, L., \& Liang, Z. (2020). Twodimensional skiving and cutting stock problem with setup cost based on column-and-row generation. European Journal of Operational Research, 286(2), 547-563. https://doi. org/10.1016/j.ejor.2020.03.060.

13. Arenales, Marcos Nereu, Cherri, Adriana Cristina, Nascimento, Douglas N. do, \& Vianna, Andréa (2015). A new mathematical model for the cutting stock/leftover problem. Pesquisa Operacional, 35(3), 509-522. https://doi.org/10.1590 /01017438.2015.035.03.0509.

\section{Математична модель мінімізації витрат металу шляхом урахування розкроювання заготовок у двох переділах}

\section{В. В.Гнатушенко, Т. А. Желдак, Л. С. Коряшкіна}

Національний технічний університет «Дніпровська політехніка», м. Дніпро. Україна, e-mail: zheldak.t.a@nmu.one

Мета. Забезпечення зниження енергетичних і peсурсних витрат під час багатоетапного виробництва прокатної продукції в межах заданого плану за рахунок розробки відповідного математичного забезпечення.

Методика. Математичне забезпечення багатоетапних задач виробництва прокатної продукції розроблено на основі системного підходу із використанням основних положень теорії оптимізації й дослідження операцій. Реалізація розробленої математичної моделі дає можливість знайти таку стратегію використання металу під час усього процесу виробництва продукції, за якої мінімізуються не тільки втрати металу в момент його розливки до 
виливниць, але й обрізки в ході розкроювання отриманих зливків на передільні заготовки.

Результати. Побудована математична модель задачі мінімізації кількості металу, використаного для виготовлення певного замовлення, розмір якого не перевищує об'єм однієї плавки. Розроблена модель враховує можливість наперед оцінити оптимальний розмір передільної заготовки, виходячи з бажаного розкроювання за довжиною готової продукції, допустимих для даної продукції профілів передільної заготовки та обмежень на вагу одного зливка.

Наукова новизна. Запропонована математична модель оптимального процесу розподілу металу на виконання плану виробництва прокатної продукції, що, на відміну від існуючих, переносить акцент оптимізації на формування оптимальної ваги зливка, що має наперед розраховане оптимальне розкроювання.

Практична значимість. Використання розробленої математичної моделі мінімізації кількості металу, використаного для виготовлення певного замовлення, у складі автоматизованої системи підтримки прийняття рішень керування прокатним виробництвом дозволить зменшити кількість переналадок обладнання різальних машин і мінімізує використання ресурсів і залишків продукції на складі.

Ключові слова: розливка металу, зливок, витратний коефіцієнт металу, мірність, оптимізація, двоетапна модель

\section{Математическая модель минимизации затрат металла путем учета раскроя заготовок в двух переделах}

\section{В. В. Гнатушенко, Т. А. Желдак, Л. С. Коряшкина}

Национальный технический университет «Днепровская политехника», г. Днепр. Украина, e-mail: zheldak.t.a@ nmu.one

Цель. Обеспечение снижения энергетических и ресурсных затрат при многоэтапном производстве прокатной продукции в пределах заданного плана за счет раз- работки соответствующего математического обеспечения.

Методика. Математическое обеспечение многоэтапных задач производства прокатной продукции разработано на основе системного подхода с использованием основных положений теории оптимизации и исследования операций. Реализация разработанной математической модели дает возможность найти такую стратегию использования металла в течение всего процесса производства продукции, при которой минимизируются не только потери металла в момент его разливки в изложницы, но и обрезки в ходе раскроя полученных слитков на передельные заготовки.

Результаты. Построена математическая модель задачи минимизации количества металла, использованного для изготовления определенного заказа, размер которого не превышает объем одной плавки. Разработанная модель учитывает возможность заранее оценить оптимальный размер передельной заготовки, исходя из желаемого раскроя по длине готовой продукции, допустимой для данной продукции профилей передельной заготовки, и ограничений на вес одного слитка.

Научная новизна. Предложена математическая модель оптимального распределения металла при выполнении плана производства прокатной продукции, которая, в отличие от существующих, переносит акцент оптимизации на формирование оптимального веса слитка, который имеет заранее рассчитанный оптимальный план раскроя.

Практическая значимость. Использование разработанной математической модели минимизации количества металла, используемого для изготовления определенного заказа, в составе автоматизированной системы поддержки принятия решений для управления прокатным производством позволит снизить количество переналадок оборудования резальных машин и минимизирует использование ресурсов и количество остатков на складе.

Ключевые слова: разливка металла, слиток, расходный коэффициент металла, мерность, оптимизация, двухэтапная модель

Recommended for publication by A. I. Huda, Doctor of Technical Sciences. The manuscript was submitted 28.11.20. 